\title{
The Validity of the Pop-Up Book Media on Puberty Topics for Sixth Grade Elementary School
}

\author{
Ni Luh Dina Viana Sari ${ }^{1 *}$, Nyoman Kusmariyatni ${ }^{2}$
}

${ }^{123}$ Elementary School Teacher Education Study Program, FIP, Undiksha, Indonesia

\author{
A RTICLEINFO \\ Article history: \\ Received 18 March 2020 \\ Received in revised form \\ 30 April 2020 \\ Accepted 5 May 2020 \\ Available online 15 May \\ 2020 \\ kata kunci: \\ media, pop-up book, masa \\ pubertas \\ keywords: \\ media, pop-up book, puberty
}

\begin{abstract}
A B S T R A K
Penelitian ini didasari atas keterbatasan materi pada buku siswa dan minimnya penggunaan media dalam proses pembelajaran. Penelitian ini bertujuan untuk mengembangkan media pop-up book pada topik masa pubertas kelas VI sekolah dasar. Pelaksanaan penelitian ini mengacu pada prosedur model pengembangan yang terdiri dari tahap Analyze, Design, Development, Implementation, and Evaluation. Subjek penelitian ini adalah media pop-up book, sedangkan objek dalam penelitian ini adalah validitas media pop-up book. Pengumpulan data dalam penelitian ini menggunakan metode kuesioner. Untuk mengetahui validitas media pop-up book, digunakan instrumen rating scale berupa lembar penilaian yang diberikan kepada empat ahli. Data hasil validasi kemudian dianalisis menggunakan rumus mean untuk mengetahui rata-rata skor validitas media pop-up book. Hasil analisis menunjukkan, rata-rata skor validasi media pop-up book yaitu 4,86 dengan kualifikasi sangat baik. Media ini dapat digunakan dalam proses pembelajaran. Guru akan terbantu dalam menyampaikan materi dan siswa dapat memahami materi serta ikut berperan aktif dalam pembelajaran.
\end{abstract}

\section{ABS TRACT}

This research is based on the limitations of the material in student books and the lack of use of media in the learning process. This study aimed at developing a pop-up book media on the topic of puberty class VI in elementary school. The implementation of this research referred to the procedure of the development model which consisted of the Analyze, Design, Development, Implementation, and Evaluation stages. The subject of this research was the pop-up book media, while the object in this study was the validity of the pop-up book media. Data collection in this study used a questionnaire method. To determine the validity of the pop-up book media, a rating scale instrument was used in the form of an assessment sheet given to four experts. The validation data was then analyzed using the mean formula to find out the average score of the validity of the pop-up book media. The analysis showed the average score of validation of pop-up book media is 4.86 with very good qualifications. This media can be used in the learning process. The teacher will be helped in delivering the material and students can understand the material and take an active role in learning.

\section{Pendahuluan}

Short learning can be interpreted as a complex activity to teach students in achieving the expected goals through the conscious effort of the teacher (Trianto, 2012). Learning is also defined as an activity to achieve curriculum goals by someone through the efforts and professional knowledge of the teacher (Kosasih, 2014). Based on this understanding it can be seen that students learning to achieve the expected goals. An effort should be made by the teacher based on professional knowledge possessed. This effort can be realized if the teacher understands his duties and roles as educators.

As educators, teachers have the main task of directing, guiding, educating, teaching, training and evaluating (Teacher and Lecturer Law). Besides having the main task, the teacher also acts as a facilitator and mediator. The teacher as the facilitator has the role of providing the facilities needed by students in learning so that they can receive material optimally. Whereas as a mediator, the teacher plays a role in changing student behavior and seeks to provide or use media in learning (Minsih \& Galih, 2018). The teacher's role as a facilitator and mediator is the teacher's role to provide the facilities needed by students in the learning process, including providing media. The teacher is

Copyright (C) Universitas Pendidikan Ganesha. All rights reserved.

\footnotetext{
1 Corresponding author.
}

E-mail addresses: dinavianasari@gmail.com ${ }^{1}$ (Dina), pakgun pgsd@yahoo.com² $\left(\right.$ Marguna), nym kusmariyatni@yahoo.com ${ }^{3}\left(K_{u s m a r i y a t n i)}\right.$ 
expected to be able to develop media, so they can be used and help students understand the material in learning (Darimi, 2017).

Media is a communication channel used by teachers to deliver messages to recipients (Reffiane \& Mazidati, 2016). The media use to simplify and concretize concepts that are complex and abstract so that they are easily understood by students (Baharun, 2016). Submission of material that is unclear can be assisted with the delivery of media. The use of media must be adapted to the characteristics of students to achieve the expected goals and can make students activate learning (Masturah, Mahadewi, \& Simamora, 2018). To make learning achievement more effective, the existence of media is needed (Darimi, 2017). Media has a role and usefulness in the learning process. The media's role is to clarify the material presented. The media also acts as stimulation of student learning as well as a source of questions and learning resources. While the use of media is to equalize perception, clarify verbal messages, increase willingness to learn, overcome the limitations of space, time, and senses, and enable students to learn independently (Mustika, 2015). Media can be used as a link between material and reality by including appropriate content or images to make it easier for students to understand and remember in the longer term (Zainorrahman, Azizah, \& Kadarisman, 2018).

The use of media in learning is still minimum. For the most part, teachers only utilize student books and pictures that delivering the material, even though the material in the book is still limited and general. Based on the study of documents in the seventh-grade students' books even semester, there is material content that is still limited, especially subject matter science. This is supported based on the results of a questionnaire distributed on November 7-13, 2019 to sixth-grade elementary school teachers in the Kecamatan Sukasada in the fifth grade 2019/2020 academic year. The results of the questionnaire showed: (1) 100\% of teachers stated that in student learning always used the student book (thematic books) that had been provided, including the content of the science contained in it, (2) $54 \%$ of the teachers stated that the material contained in the student's book was narrow, (3) $52 \%$ of teachers stated that lack of material content of science in students book. The limitations of the material content of science in student books can be one of the causes of decreased student understanding in the field of science. This is proven by the results of the 2018 PISA issued by the OECD (Organization for Economic Co-operation and Development). The scientific ability of Indonesian students obtained an average score of 389, while the OECD average score was 489 (Indriani, 2019). If it continues, it does not rule out the possibility that Indonesia will continue to downgrade ranking or score in science capabilities at the national and international levels. For this reason, it is necessary to know the materials that are felt to need to get more understanding. It is necessary to know what topics need to be developed in student learning manuals.

To find out the topic of science content that is still limited, further interviews were conducted with the sixth-grade teachers of the Sekolah Dasar Gugus 5, Kecamatan Sukasada. The interview results showed topics that need to be developed. One of these topics is puberty. The limited material on puberty topics confused students to find additional information, so they have learning difficulties and actively participate in learning. The limited material on the topic of puberty also affects the teacher. Teachers must be prepared with other references to facilitate their students to get additional information related to the topic. The teacher presented the topic of puberty requires media as an intermediary. New creations and innovations are needed to make capable media of puberty topics and attracting students' attention. Innovations and creations that can be done are developing puberty topics in the form of pop-up book media.

Pop-up book media is media that is composed of pieces of images that when a page is opened will cause three-dimensional elements (Fitriani \& Fajriyah, 2017). Pop-up book media is an innovative media that can involve students in learning (Sari \& Ulya, 2017). The advantage of the pop-up book media with other media lies in the visuals which contain many images, so it looks more realistic and interesting (Mustofa \& Shafi'ah, 2018). There are techniques used in pop-up book media: (1) transformation, vertically arranged pop-up techniques; (2) volvelles, using circular elements; (3) peepshow, using stacks of paper to create the illusion of depth; (4) pull-tabs, techniques for displaying motion by being pulled and pushed; (5) carousel, using ribbons or straps that can be opened and folded back; and (6) box and cylinder, using box and cylinder elements that can move when the yard is opened (Masturah et al., 2018).

The use of pop-up book media can help to deliver material and increase curiosity and enthusiasm of students to participate in learning. A pop-up book can be independently used at school or outside school (Mustofa \& Syafi'ah, 2018). In addition, the pop-up book media is relevant to use in science learning because it contains abstract concepts. Through the use of pop-up book media, material features will be more easily understood by students (Permana \& Sari, 2018). This is proved by Mustofa \& Syafi'ah's research (2018) which states that pop-up book media is suitable for use in elementary 
science lessons. Similar research was also carried out by Devi \& Maisaroh (2017). The results of the study stated that the development of pop-up book media can be implemented for elementary school levels and can improve student achievement. Media validation meets the very well category with an average score of media experts 4.05 and 4.50 from the material experts. Student responses to the media reached $93.33 \%$ and 4.50 of the teachers in a very good category. In addition, research related to pop-up book media was also carried out by Baiduri, Taufik, \& Elfiani (2019). The results showed that pop-up book media was effective and suitable for use in learning. This is based on the results of the validation which received $88.16 \%$ of media experts and learning practitioners and $87 \%$ of student learning outcomes in a classical way. Based on the results of research that has been carried out, the development of pop-up book media is believed to be valid and appropriate for use in learning.

Based on the description above, a study was conducted to develop a pop-up book media, especially on the topic of puberty in the sixth grade of elementary school because this topic was deemed necessary to be developed. This research was supported by the results of a questionnaire given to students and sixth-grade elementary school teachers in Kecamatan Sukasada in academic year $2019 / 2020,72 \%$ of students answered that they really need to develop science content material in the form of pop-up books and $78 \%$ of teachers strongly agree if the content material Science is developed in the form of pop-up book media, specifically the topic of puberty. Therefore, a study was carried out aimed at producing pop-up media on the topic of puberty in the sixth grade of elementary schools in the Cluster Five District Sukasada in the academic year 2019/2020 which had been tested for validity.

\section{Method}

This research was research development. It is referred to as the ADDIE model. The selection of this model was based on considerations that it was easy to understand and based on theoretical learning designs. This model was structured and programmed with a sequence of systematic activities to solve learning problems according to the needs and characteristics of students. ADDIE model consists of five stages, namely: (1) analysis (analysis), (2) design, (3) development, (4) implementation, and (5) evaluation (Tegeh, Jampel, \& Pudjawan, 2014). This research was carried out based on the ADDIE development model. The implementation and evaluation stages in this study were not carried out because of limited time, resources, and finances.

The first stage carried out is the analysis phase. The analysis phase consisted of four activities: (1) needs analysis is carried out to find out information in the field related to problems in the learning process, (2) analysis of student characteristics is carried out to determine the characteristics and level of understanding of students who are being targeted by using pop-up book media, (3) curriculum analysis is carried out by reviewing the syllabus, core competencies (KI), and basic competencies (KD) on the puberty topic of sixth grade which adjusted to the subject matter, and (4) media analysis is carried out to gather information related to good media criteria so that it can be used as a reference in the development of media for elementary school students.

The design phase began by determining the design of pop-up book media on the puberty topic in the sixth grade of elementary school. The completed design was then consulted with the supervisor to get suggestions and input so that improvements could be carried out and continued at the development stage.

The development phase was carried out by developing a pop-up book media on the puberty topic in sixth-grade elementary school based on the design and advice of the supervisor. After the development finished, it was followed by an expert test to review the pop-up book media that have been developed. The expert test was carried out by providing an assessment sheet to the expert consist of two lecturers and two teachers as media experts and science experts.

The subject of this research was the pop-up book media on the puberty topic in the sixth grade of elementary school. The object of this research was the validity of pop-up book media on the puberty topic in the sixth grade of elementary school. Data collection methods in this study used a questionnaire method in the form of statements consists of 13 statements. Data collection instruments in this study used instruments in the form of a rating scale. The rating scale was data in the form of numbers that can be interpreted descriptively, for example, positive-negative and large-small (Ilhami \& Rimantho, 2017). The form of the rating scale was based on a certain scale, both from high to low or low to high. The rating scale used a 5-1 scale. The instrument in this study referred to the media development consists of six aspects, cover, format, content, language, practical, and effective aspects (Yamasari, 2010). The six aspects were made in the form of instruments based on the criteria of each aspect: (1) the cover aspect includes the identity of the media and the attractiveness of the cover; (2) criteria for format aspects include color, text, letters, and layout; (3) the content aspect criteria include 
the suitability of the material with the indicators, the ability of the media to explain the material, the completeness of the material, and the attractiveness of the material; (4) the criteria of language aspect includes language use, language standardization, sentence effectiveness, and word usage; (5) criteria for practical aspects related to media use; and (6) the criteria for effective aspects are also related to the use of media (Monika, Laila, \& Eka, 2014).

Data analysis methods and techniques used in this study are descriptive qualitative and quantitative analysis methods. The descriptive qualitative analysis method was used to process data in the form of input, responses, criticisms, and suggestions from the results of the experts' review of the developed media. The quantitative descriptive analysis method was used to describe the score of each expert who gives an assessment sheet. The scores averaged using the mean formula to find out the validity of the media. The average score converted to the five-scale conversion guidelines to determine the validity and qualifications of the puberty pop-up book media. The study said to be successful if the average score of media validity was $3.33<\mathrm{X} \leq 4.00$ with a good category.

\section{Results and Discussion}

This research was carried out to develop pop-up book media on the puberty topic in sixth grade at SD Gugus 5 Kecamatan Sukasada academic year 2019/2020. The results of this study are in the form of pop-up book media on puberty topics in the sixth grade of elementary school which is already valid. Based on the results of data analysis using the mean formula, the results show that the average score of the validity of the pop-up book media on puberty topics was 4.86. If converted to the five scale guidelines, it is in a very good qualification. The results of the validity can be seen in Figure 1.

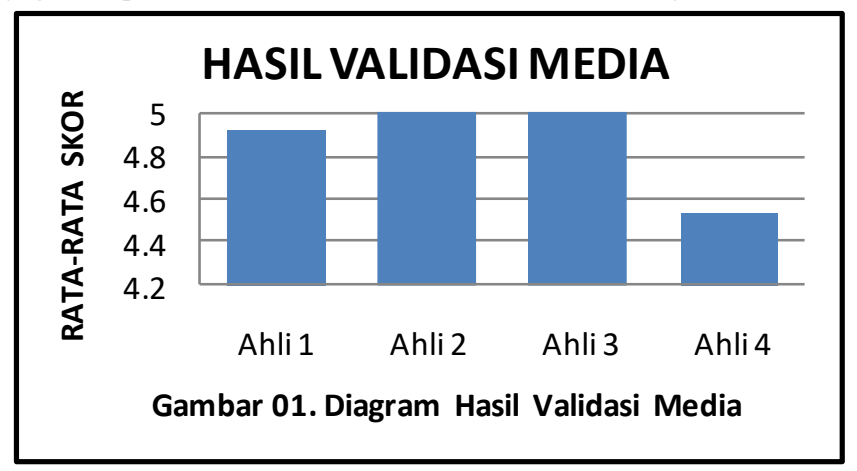

Figure 1

The results of the validity

This study aimed to produce pop-up book media on puberty topics. Pop-up book media is important for overcoming learning problems, especially the use of media. Pop-up book media contains a lot of pictures and elements of color and motion, increasing students' imagination (Fitriani \& Fajriyah, 2017). The pop-up book media produced can be seen in Figure 2.

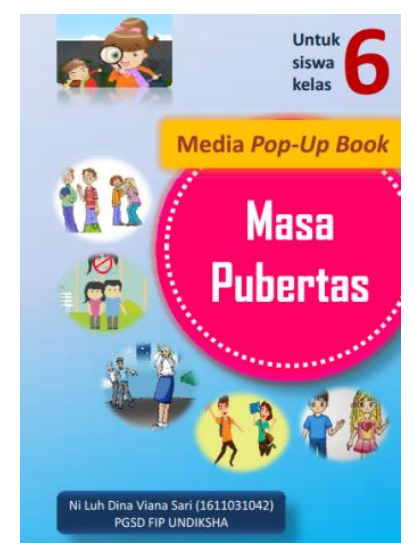

(a) Front Cover

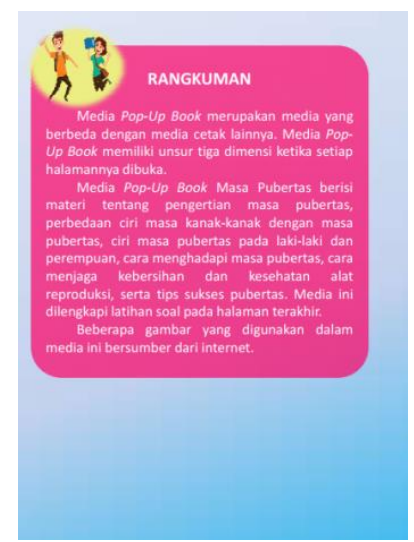

(b) Back Cover 

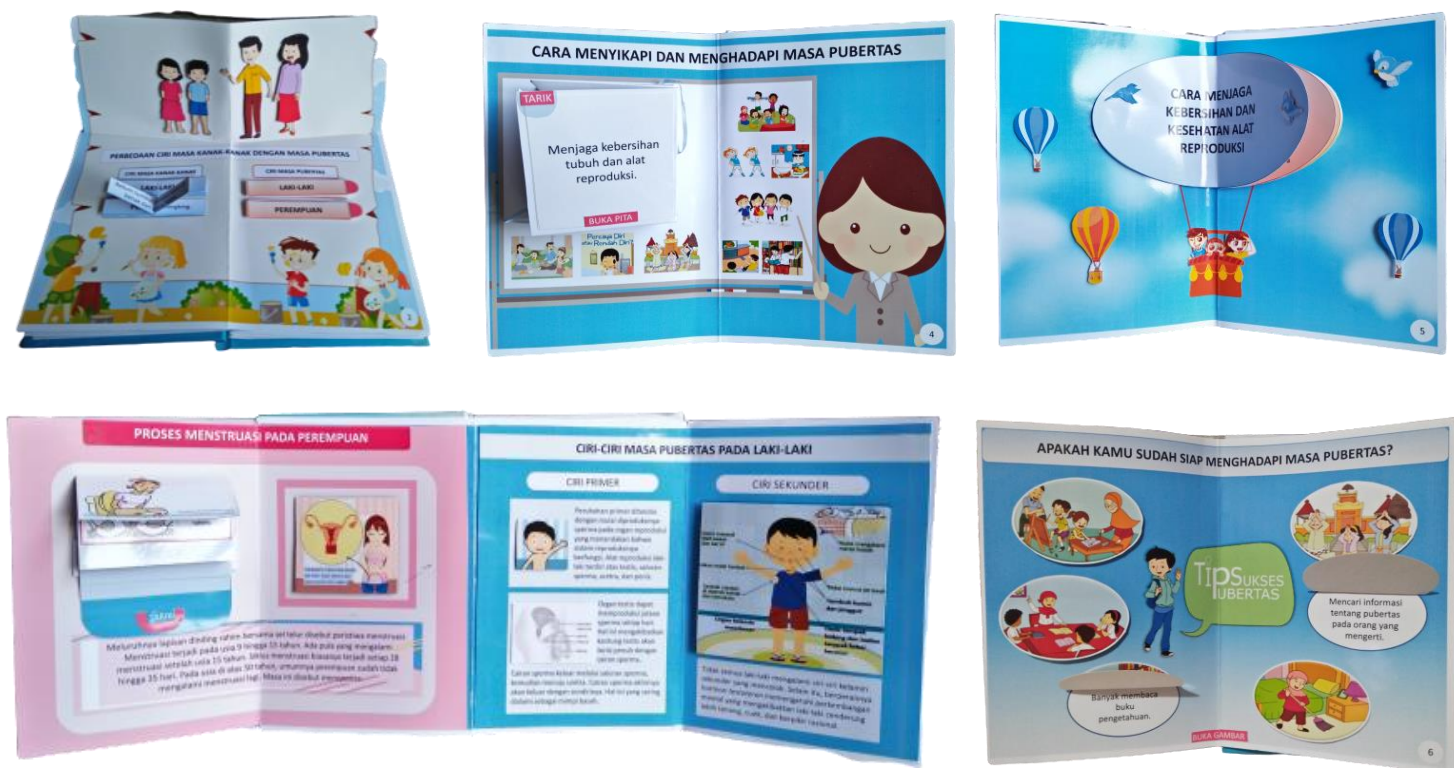

(c) The Media Pop-Up Book content

Figure 2

Pop-Up Book media

Based on the previous explanation, this study used the ADDIE development model which consisted of (1) analysis, (2) design, (3) development, (4) implementation, and (5) evaluation. Due to limited time, resources, and finances, development procedures are carried out until the development stage.

The analysis phase was carried out through needs analysis, student characteristics, curriculum, and media analysis. Based on the results of the needs analysis, it is known that the material content of science in student books is still limited, includes the topic of puberty. Based on the results of the questionnaire, it is known that (1) $100 \%$ of teachers stated that in learning students always use the student books (thematic books) that have been provided, includes the science content contained in them, (2) $54 \%$ of teachers stated that the material contained in the science narrow students, and (3) $52 \%$ of the teachers stated that the material contained in the Natural Sciences student book was not deep enough. In addition, it is known that the lack of use of media in the learning process in SD Gugus 5 Kecamatan Sukasada 2019/2020 academic year, even though the use of media is an important component that must be present in learning. Media can be used as a link between material and reality by including content or images to help and facilitate students to understand and remember the material in the longer term (Zainorrahman et al., 2018). Based on that, an interesting media was developed, pop-up book media on puberty topic of which contains many images, so that it can help visualize the material.

Analysis of student characteristics was carried out to determine the condition of the target students. Based on the analysis of student characteristics, students need real objects or images to understand the material. This is in line with Piaget's theory of cognitive development which states the age of primary school children is at a concrete operational stage (Ibda, 2015). Therefore students need media as an intermediary. Besides that, the sixth-grade elementary school students in Gugus 5 Kecamatan Sukasada already have reading skills, so students believed to be able to understand the material on the media and use the media well.

Curriculum analysis was performed to determine the material in the developed media. The analysis was carried out by examining the syllabus, core competencies, and basic competency topics of puberty which adjusted to the material in the student's book. The results of curriculum analysis in the form of indicators consist of four indicators which are the translation of basic competencies. The four indicators are: (1) understanding the meaning of puberty, (2) distinguishing the characteristics of childhood with puberty, (3) comparing the characteristics of puberty in men and women, and (4) linking the characteristics of puberty in men and women with reproductive health through how to deal with puberty and how to maintain the cleanliness of the reproductive organs. Based on the four indicators, the topic of puberty developed which still refers to basic competencies.

Media analysis was done to gather information about good media criteria. Based on the analysis, good media was media that able to deliver messages or information to the recipient of the message. 
Good media can help students' understanding, both through pictures, explanations, and others. The media had used in the learning process: (1) clarifying verbal messages, (2) overcoming the limitations of space, time, and senses, (3) enhancing perception, (4) give learning desires, and (5) making it possible to help students learn independently according to talent and ability (Mustika, 2015).

After the analysis was carried out, proceed to the design stage. The design phase carried out by making a pop-up book media design on the puberty topic in sixth grade elementary school, starting from the cover and design as well as the material contained on each page. Media planning created with the help of power points. The media designed with A5 paper size $(14.8 \mathrm{~cm}$ x $21 \mathrm{~cm})$ consisted of seven pages. The design stage also determines which pop-up techniques will be used. The completed design consulted with a supervisor. The consultation results in the form of suggestions and input to improve the media design, so it can be improved. The suggestions are (1) the images used in the media must not obstruct or overlap, (2) the images used must be adjusted to the material, (3) the use of techniques so as not to obstruct the readability of the material on the media, (4) the quality of the images used needs to be considered, and (5) the selection of colors, text, and font size must be adjusted, so they look harmonious and connected. This input used as a reference in implementing the media development stage.

The development phase began with collecting and preparing tools and materials used in the development of puberty pop-up book media. It ensures the material and design used on each page. The media was developed with an attractive cover design and there was a summary on the back cover of the media. The media also equipped with instructions to use the media, basic competencies and indicators, and a table of contents. Each page printed using a glossy paper. In addition, the pop-up techniques used on each page began to be compiled. Puberty pop-up media was developed into seven pages.

The first page of the media contains material understanding puberty with open techniques. The second page contains material differences in the characteristics of childhood with puberty, using a box and up techniques. The third page contains material about the characteristics of puberty in men and women with open and pull-tab techniques. The fourth page contains material on how to address and deal with puberty with carousel techniques. The fifth page contains material on how to maintain the cleanliness and health of the reproductive organs, using the cylinder technique. The sixth page contains tips on successful puberty with the lift of the flap technique. On the last page contains the question exercise which consists of eight items and is equipped with answer keys. The technique used is the open technique.

There are techniques used in this pop-up book media to take references and be selected based on research by Masturah et al. (2018) consists of: (1) transformation, a vertical pop-up cut technique; (2) volvelles, using circular elements; (3) peepshow, using stacks of paper to create the illusion of depth; (4) pull-tabs, techniques for displaying motion by being pulled and pushed; (5) carousel, using ribbons or straps that can be opened and folded back; and (6) box and cylinder, using box and cylinder elements that can move when the yard is opened (Masturah et al., 2018).

After the media developed, an assessment or review carried out by media experts and Natural Sciences experts consists of two lecturers and two teachers. The review was done by giving an assessment sheet. The data from the review results analyzed to determine the validity of the media. While the results of the review in the form of comments and suggestions used as considerations to make revisions to the developed media. Based on the results of data analysis, the average score of puberty pop-up book validation was 4.86 with very good qualifications.

Based on the results of the validity and qualifications, it indicated that the development of popup book media was valid and had very good qualifications. If this media implemented in learning, it believes to get a positive response from students and teachers and can be used in the learning process. It based on the use of media that can link material with reality through content or images that appropriate to make it easier for students to understand and remember in the longer term (Zainorrahman et al., 2018). The pictures contained in the pop-up book media can provide visualization of the material to students, students helped to understand the material presented. Through the use of pop-up book media, students will more easily understand the material features (Permana \& Sari, 2018). The use of pop-up book media in learning increases students' imagination of the material because there are pictures, colors, and elements of motion (Fitriani \& Fajriyah, 2017).

The advantages of book-pop-up media if compared to other media are: (1) it is made using thick paper so that it is not easily damaged or torn, (2) each page contains interesting images and can arise when opened, (3) can be used in the learning process, both independent or in groups (Anggraini, 2019). Based on the results of research conducted by Masturah et al. (2018) shows the validity of the pop-up book media valid with the percentage of expert content review $95.8 \%$ (very good), $88 \%$ design 
expert (good), learning media experts $98.5 \%$ (very good), individual test $92 \%$ (very good), small group test $91.67 \%$ (very good), and $90.08 \%$ field test (very good). Similar research was also carried out by Devi \& Maisaroh (2017). The results of the study stated that the development of pop-up book media can be utilized for elementary school levels and can improve student achievement. Media validation meets very well category with an average score of media experts 4.05 and 4.50 from the material experts. Student responses to the media reached $93.33 \%$ and 4.50 of the teachers in a very good category. In addition, the development of pop-up book media was also carried out by Mustofa \& Syafi'ah (2018). The results of the study stated that the pop-up book media is suitable for use in elementary science subjects with an average score of 4.44 from material experts, 4.80 from media experts, and 4.72 from users. All three scores are in the excellent category. Based on the results of research that have been carried out and similar research results, the pop-up book media on puberty topic when implemented is believed to get a good response from teachers and students and can be utilized in the learning process.

\section{Conclusion}

Based on the results of research and discussion, it can be concluded that the development of pop-up book media on the puberty in the sixth grade of elementary schools in the Cluster Five District Sukasada in the academic year 2019/2020 was valid by of 4.86 average scores, in very good qualifications. If this media is implemented in learning, it is believed to get a positive response from students and teachers and can be used in the learning process.

Based on the results of the research that has been carried out, some suggestions that can be delivered are, the development of the media pop-up book can be used as a reference by the teacher in developing innovative media and can develop material. It is hoped that the teacher can also develop pop-up book media with other topics to attract students' attention. In addition, the principal is expected to facilitate teachers to develop media skills for the learning process, both through training and so on. For other researchers, this research can be used as a reference in carrying out similar research. Other researchers can also continue this research on the implementation and evaluation stages through experiments.

\section{References}

Anggraini. (2019). Development of Pop-up book Integrated with Quranic Verses Learning Media on Temperature and Changes in Matter. Journal of Physics, 1-9.

Baharun, H. (2016). Pengembangan Media Pembelajaran PAI Berbasis Lingkungan Melalui Model ASSURE. Cendekia: Journal of Education and Society, 14(2), 231-246. https://doi.org/10.21154/cendekia.v14i2.610

Baiduri, Taufik, M., \& Elfiani, L. (2019). Pengembangan Media Pembelajaran Pop-Up Book Berbasis Audio Pada Materi Bangun Datar Segiempat Di SMP. Jurnal Program Studi Pendidikan Matematika, 8(1), 248-261.

Darimi, I. (2017). Teknologi Informasi dan Komunikasi sebagai Media Pembelajaran Pendidikan Agama Islam Efektif. Jurnal Pendidikan Teknologi Informasi, 1(2), 111-121.

Devi, A. S., \& Maisaroh, S. (2017). Pengembangan Media Pembelajaran Buku Pop-Up Wayang Tokoh Pandhawa Pada Mata Pelajaran Bahasa Jawa Kelas V SD. Jurnal PGSD Indonesia, 3(2).

Fitriani, L., \& Fajriyah, K. (2017). Pengembangan Media Pop Up Book Tema 5 Pahlawanku Pada Model Pembelajaran Numbered Head Together Kelas IV SDN 01 Gintung. Kalam Cendekia, 6(3.1), 29-

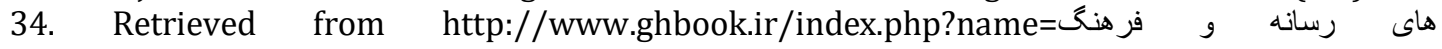
نوين وين \&Itemid=218\&lang=fa\&tmpl=component

Ibda, F. (2015). Perkembangan Kognitif: Teori Jean Piaget. Jurnal Intelektualita, 3(1), 27-38.

Ilhami, R. S., \& Rimantho, D. (2017). Penilaian Kinerja Karyawan dengan Metode AHP dan Rating scale. Jurnal Optimasi Sistem Industri, 16(2), 150-157.

Indriani. (2019). Hasil PISA Tunjukkan Perspektif Pendidikan Indonesia. Antara News.

Kosasih. (2014). Strategi Belajar dan Pembelajaran. Bandung: Yrama Widya. 
Masturah, E. D., Mahadewi, L. P. P., \& Simamora, A. H. (2018). Pengembangan Media Pembelajaran PopUp Book Pada Mata Pelajaran IPA Kelas III Sekolah Dasar. Jurnal Edutech Universitas Pendidikan Ganesha, 6(2), 212-221. https://doi.org/10.21067/jbpd.v2i2.2495

Minsih, \& Galih, A. (2018). Peran Guru Dalam Pengelolaan Kelas. Profesi Pendidikan Dasar, 5(1), 20-27. https://doi.org/10.23917/ppd.v1i1.6144

Monika, I., Laila, F. Y., \& Eka, A. (2014). Uji Aktivitas Ekstrak Kencur Terhadap Pengendalian Pertumbuhan Fusarium oxysporum dan Implementasinya dalam Pembuatan Flipbook. Jurnal Pendidikan Dan Pembelajaran Khatulistiwa, 3(2), 1-14.

Mustika, Z. (2015). Urgenitas Media Dalam Mendukung Proses Pembelajaran yang Kondusif. Jurnal Ilmiah CIRCUIT, 1(1), 60-73.

Mustofa, R., \& Syafi'ah, R. (2018). Pengembangan media pembelajaran pop up book else ( Elementary School Education Journal ). Elemntary School Education Journal, 2(2), 30-41.

Permana, E. P., \& Sari, Y. E. P. (2018). Development of Pop Up Book Media Material Distinguishing Characteristics of Healthy and Unfit Environments Class III Students Elementary School. International Journal of Elementary Education, 2(1), 8-14. https://doi.org/http://dx.doi.org/ 10.23887/ijee.v1i1.13127

Reffiane, F., \& Mazidati, I. (2016). Implementasi Pengembangan Media Wayang Kerton Pada Tema Kegiatan Sehari-Hari. Mimbar Sekolah Dasar, 3(2), 163-170. https://doi.org/10.23819/mimbarsd.v3i2.4256

Sari, S. A., \& Ulya, A. (2017). The Development of Pop-up Book on the Role of Buffer in the Living Body. European Journal of Social Sciences Education and Research, 4(4), 213-221. https://doi.org/10.26417/ejser.v10i2.p213-221

Tegeh, Jampel, \& Pudjawan. (2014). Model Penelitian Pengembangan. Yogyakarta: Graha Ilmu.

Trianto. (2012). Mendesain Model Pembelajaran Inovatif-Progresif. Jakarta: Kencana Prenada Media Group.

Yamasari, Y. (2010). Pengembangan Media Pembelajaran Matematika Berbasis ICT yang Berkualitas. Surabaya.

Zainorrahman, Azizah, L. F., \& Kadarisman. (2018). Pengembangan media berbasis pop up book untuk pembelajaran ipa di mts raudhatut thalibin. Alpen: Jurnal Pendidikan Dasar, 2(2), 99-106. 